\title{
Chronic Encapsulated Intracerebral Hematoma Associated With Cavernous Angioma
}

\author{
-Case Report-
}

\begin{abstract}
Kosuke MiYahara, ${ }^{1}$ Kazuhiko FUjITSU, ${ }^{1}$ Saburo Yagishita, ${ }^{2}$ Teruo ICHIKAWA, ${ }^{1}$ Yasunori TAKEMOTO, ${ }^{1}$ Tomu OKADA, ${ }^{1}$ Hitoshi NIINO, ${ }^{3}$ and Takeki SHIINA ${ }^{4}$
\end{abstract}

\author{
Departments of ${ }^{1}$ Neurosurgery, ${ }^{3}$ Pathology, and ${ }^{4}$ Radiology, \\ National Hospital Organization Yokohama Medical Center, Yokohama, Kanagawa; \\ ${ }^{2}$ Department of Pathology, Kanagawa Rehabilitation Center, Atsugi, Kanagawa
}

\begin{abstract}
An 80-year-old male presented with a chronic encapsulated intracerebral hematoma (CEIH) with surrounding edema under the right frontal lobe manifesting as slow exacerbation of disturbance of orientation and gait. He had a history of cerebral infarction with an asymptomatic cavernous angioma in the right frontal lobe. The CEIH was diagnosed as bleeding from the cavernous angioma, and surgical removal was performed. The hematoma was chronic and covered by a thick capsule. In addition, mass tissue covered with the organized hematoma was found near the capsule, which was excised and found to be a cavernous angioma. CEIH is a special type of intracerebral hemorrhage, and bleeding from a cavernous angioma is occasionally seen. CEIH should be considered in the case of a hemorrhagic intracranial lesion with a chronic, progressive course with capsule formation and edema around the lesion. The source of bleeding is unknown in about half of the reported cases, and occult vascular malformation may be involved, necessitating care in diagnosis.
\end{abstract}

Key words: cavernous angioma, chronic encapsulated hematoma, intracerebral hematoma, vascular malformation, fibrous capsule

\section{Introduction}

Intracerebral hematoma sometimes grows slowly while forming a capsule and manifesting as the symptoms of a space-occupying lesion, and is then termed a chronic encapsulated intracerebral hematoma (CEIH). We experienced a case of frontal CEIH formed by hemorrhage from a cavernous angioma, and report the pathological findings and therapeutic strategy for this disease.

\section{Case Report}

An 80-year-old man was hospitalized with right hemiparesis, as a sequela of cerebral infarction. Computed tomography (CT) showed the old cerebral infarction in the left corona radiata and a cavernous angioma of about $1-\mathrm{cm}$ diameter in the right frontal lobe in March 2006 (Fig. 1). The patient showed slowly progressive decrease in activity and disturbance of gait from the middle of April 2007, so he was hospitalized in our department.

Neurological examination on admission revealed disturbance of orientation and moderate left hemiparesis. CT revealed an intracerebral hematoma surrounded by strong edema under the right frontal lobe, and a high density

Received February 4, 2010; Accepted May 24, 2010

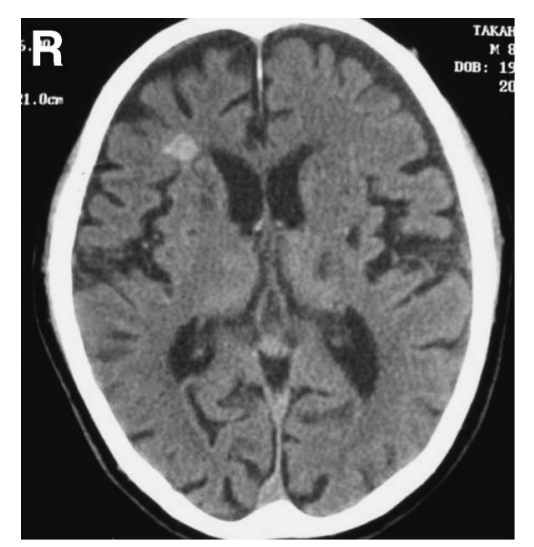

Fig. 1 Computed tomography scan before admission showing a high density mass lesion with a diameter of $1 \mathrm{~cm}$ in the right frontal lobe.

region in the hematoma which appeared to have been caused by bleeding of the cavernous angioma (Fig. 2). $\mathrm{T}_{2^{-}}$ weighted magnetic resonance imaging immediately after admission showed the hematoma as mixed intensities with low intensity rim suggestive of hemosiderin deposition (Fig. 3). The hematoma was removed through a 


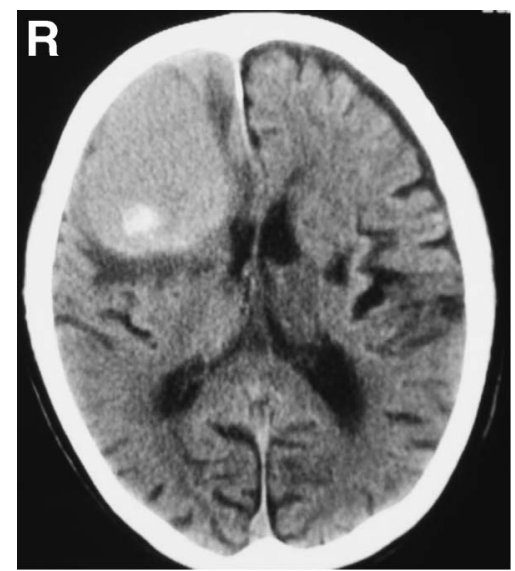

Fig. 2 Computed tomography scan on admission showing an isodense space-occupying lesion below the cortex of the right frontal lobe with perifocal edema.

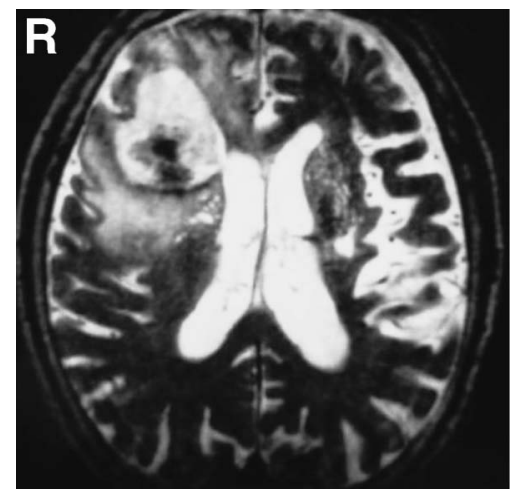

Fig. $3 \quad T_{2}$-weighted magnetic resonance image showing a high intensity space-occupying lesion surrounded by a low intensity rim.

craniotomy under a diagnosis of CEIH formed by bleeding from the cavernous angioma.

Right frontal craniotomy was performed, and the hematoma cavity was reached through the cortex. The hematoma had a thick capsule with a clear border with the surrounding tissue, and contained brownish fluid hematoma exhibiting characteristics of the chronic stage which was removed by suction. Observation of the hematoma wall revealed organized tissue with hemosiderin deposition, which was excised.

Histological examination confirmed the diagnosis of cavernous angioma. Lymphocyte infiltration from the intra-hematoma cavity side and a 3-layer structure with vascularization, including a granulomatous layer, collagenized layer, and a reactive layer of brain tissue, were observed in the hematoma capsule. Hemosiderin deposition was found around the newly formed blood vessels, suggesting that repeated bleeding from the newly formed blood vessels was involved in the growth of the hematoma (Fig. 4).

Postoperatively, the disturbance of orientation and left
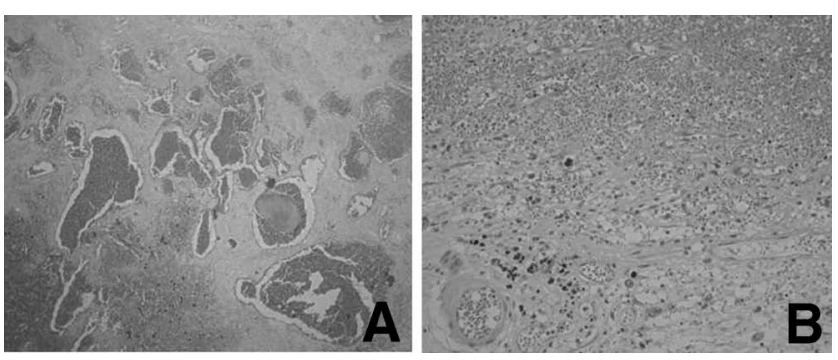

Fig. 4 Photomicrographs showing the characteristic findings of a cavernous angioma (A), and outgrowth of fibroblasts, collagenous fibers, and new blood vessels in the hematoma membrane (B). Hematoxylin and eosin stain, $\times 100$.

hemiparesis improved, and the patient was discharged. CT showed disappearance of the hematoma and cerebral edema on discharge, and the hematoma has not recurred.

\section{Discussion}

The present case involved surgical removal of a CEIH, a cavernous angioma that developed from intracerebral hemorrhage, and a capsule formed around the hematoma by chronic progressive growth. CEIH is a special type of intracerebral hematoma described for the first time in $1981,{ }^{10}$ ) with about 50 cases reported. ${ }^{1-12,14,16,18-29,31-36)}$ Compared with normal intracerebral hemorrhage, CEIH is characterized by early age of onset and rare complication by hypertension, and almost all such lesions have developed beneath the cerebral cortex. ${ }^{12)}$ Headaches and seizures are the most common earliest symptoms. Some cases have occurred in the cerebellum, ${ }^{1,2,19)}$ the basal ganglia, ${ }^{11-15,23)}$ and the lateral ventricle. ${ }^{17,21,25)}$ In about half of cases, the cause of the initial hemorrhage is malformation of a blood vessel, and in 10 cases, including the present one, the source of bleeding was cavernous angioma (Table 1). ${ }^{18,19,21,22,24,27,30)}$ Prospective study of 122 patients with intracranial cavernous angioma found the risk of hemorrhage is $2.63 \%$ per year, and the risk increases to $4.5 \%$ per year for patients with prior hemorrhage. ${ }^{13)}$

CEIH is characterized by the presence of a thick fibrotic capsule which histologically resembles the outer capsule of chronic subdural hematoma and is thought to develop by chronic progressive growth due to repeated bleeding from the new blood vessels in the capsule. ${ }^{37)}$ Vascular endothelial growth factor may be involved in the occurrence of CEIH. Further, since both leakage from the new blood vessels and strong infiltration of lymphocytes are observed, chronic inflammation reaction is involved in the edema around the hematoma. ${ }^{33)}$

Neuroimaging shows that the lesion is surrounded by marked cerebral edema and the capsule has a ring-like shape, so CEIH is often difficult to discriminate from a brain tumor. ${ }^{8,34)}$ Definitive diagnosis requires identification of the hematoma content and hematoma capsule at surgical operation and histological diagnosis. CEIH is a benign disease with a chronic, progressive course and surgical operation often yields a good outcome. Although the 
Table 1 Summary of reported cases of encapsulated intracerebral hematoma associated with cavernous angioma

\begin{tabular}{|c|c|c|c|c|c|}
\hline Case No. & Author (Year) & Age (yrs)/Sex & Symptoms & Location & Outcome \\
\hline 1 & Masuzawa et al. (1985) & $43 / \mathrm{M}$ & seizure, hemiparesis & parietal & MD \\
\hline 2 & Steiger et al. $(1987)^{30)}$ & $21 / \mathrm{M}$ & seizure & parietal & $?$ \\
\hline 3 & & $45 / \mathrm{M}$ & increased ICP & fronto-parietal & $?$ \\
\hline 4 & Monma et al. $(1990)^{21)}$ & $29 / \mathrm{F}$ & seizure & parietal & MD \\
\hline 5 & & $32 / \mathrm{M}$ & headache & lateral ventricle & GR \\
\hline 6 & Murakami et al. (1990)22) & $14 / \mathrm{M}$ & headache & frontal & GR \\
\hline 7 & Mabuchi et al. $(1991)^{18)}$ & $43 / \mathrm{F}$ & headache, hemiparesis & parietal & GR \\
\hline 8 & Okuno et al. $(1993)^{24)}$ & $71 / \mathrm{F}$ & headache & frontal & $?$ \\
\hline 9 & Roda et al. (1993) ${ }^{27)}$ & $21 / \mathrm{F}$ & headache & frontal & GR \\
\hline 10 & Present case & $80 / \mathrm{M}$ & hemiparesis, memory disturbance & frontal & GR \\
\hline
\end{tabular}

F: female, GR: good recovery, ICP: intracranial pressure, M: male, MD: moderately disabled.

cause of bleeding is unknown in about half of reported cases, based on the bleeding site and common age of occurrence, it is reasonable to assume that some types of blood vessel malformation are involved. However, many cases of occult vascular malformation occur which cannot be histologically proven due to pressure from the surrounding tissues and destruction by bleeding. Therefore, the surgical treatment of this disease should achieve as complete removal of the lesion as possible including the capsule, considering the probable blood vessel malformation.

\section{References}

1) Aoki N, Mizuguchi K: Chronic encapsulated intracerebellar hematoma in infancy: case report. Neurosurgery 14: 594-597, 1984

2) Aoki N, Mizuguchi K: Expanding intracerebellar hematoma: a possible clinicopathological entity. Neurosurgery 18: 94-96, 1986

3) Bucciero A, Del Basso De Caro ML, Siciliano A, Tedeschi E, Carangelo B, Gammone V, Vizioli L, Cerillo A: Encapsulated intracerebral hematoma: a case report and review of the literature. Minerva Chir 53: 227-230, 1998

4) Cakir E, Kuzeyli K, Usul H, Sayin OC, Kararslan G, Peksoylu B: Ruptured chronic encapsulated intracerebral hematoma in infancy: review of the literature with a case report. Childs Nerv Syst 22: 436-439, 2006

5) Chan ST, Tse CH: Chronic encapsulated intracerebral hematoma in a young Chinese adult: case report. Neurosurgery 20: 639-641, 1987

6) d'Avella D, Germano A, Romano A, Cardia E, Tomasello F: Chronic encapsulated intracerebral hematoma: contribution of thallium-201 single photon emission computed tomography in preoperative diagnosis: case report. Neurosurgery 41: 677-679, 1997

7) Fiumara E, Gambacorta M, D’Angelo V, Ferrara M, Corona C: Chronic encapsulated intracerebral haematoma: pathogenetic and diagnostic considerations. J Neurol Neurosurg Psychiatry 52: 1296-1299, 1989

8) Gokeil Z, Odabasi Z, Atilla S, Kutukcu Y, Vural O, Yardim M: Radiological follow-up in encapsulated intracerebral hematoma mimicking intratumoural bleeding. Acta Neurol Belg 98: $27-31,1998$

9) Greiner-Perth R, Neubauer U, Schenke H: Chronic encapsulated intracerebral hematoma-a well-defined disease.
Report on two cases and review of the literature. Neurosurg Rev 20: 231-238, 1997

10) Hirsh LF, Spector HB, Bogdanoff BM: Chronic encapsulated intracerebral hematoma. Neurosurgery 9: 169-172, 1981

11) Ilkko E, Pyhtinen J, Reponen J: Chronic encapsulated intracerebral haematomas. Neuroradiology 38: 551-554, 1996

12) Kasuya J, Hashimoto $Y$, Terasaki T, Miura M, Miyayama H, Uchino M: [Chronic encapsulated intracerebral hematoma in thalamus with incongruous right homogeneous hemianopia: a case report]. Rinsho Shinkeigaku 40: 29-33, 2000 (Japanese)

13) Kondziolka D, Lunsford LD, Kestle JRW: The natural history of cerebral cavernous malformations. J Neurosurg 83: 820-824, 1995

14) Kumabe T, Kayama T, Sakurai $Y$, Ogasawara K, Niizuma $H$, Wada T, Namiki T: [Encapsulated chronic intracerebral hematoma caused by venous angioma of the basal ganglia: a case report]. No Shinkei Geka 18: 735-739, 1990 (Japanese)

15) Kurita H, Ichi S, Shiokawa Y: Chronic encapsulated intracerebral haematoma in a patient with medically intractable epilepsy. Br J Neurosurg 12: 51-53, 1998

16) Kurita H, Sasaki T, Kumamoto S, Taniguchi M, Kitanaka C, Nakaguchi H, Kirino T: Chronic encapsulated expanding hematoma in association with gamma knife stereotactic radiosurgery for a cerebral arteriovenous malformation: case report. J Neurosurg 84: 874-878, 1996

17) Lin SZ, Shih CJ, Wang YC, Tsai SH: Intracerebral hematoma simulating a new growth. Surg Neurol 21: 459-464, 1984

18) Mabuchi S, Kamiyama H, Iwasaki Y, Abe H: [Multilocular encapsulated intracerebral hematoma: a case report]. No Shinkei Geka 19: 677-679, 1991 (Japanese)

19) Masuzawa T, Saito K, Shimabukuro H, Iwasa H, Sato F: Chronic encapsulated hematomas in the brain. Acta Neuropathol 66: 24-28, 1985

20) Matsumoto K, Asari S, Nishimoto A, Namba S: [Chronic encapsulated intracerebral hematoma due to metastatic brain tumor: a case report]. No Shinkei Geka 16: 327-331, 1988 (Japanese)

21) Monma S, Ohno K, Hata H, Komatsu K, Ichimura K, Hirakawa $\mathrm{K}$ : Cavernous angioma with encapsulated intracerebral hematoma: report of two cases. Surg Neurol 34: 245-249, 1990

22) Murakami S, Sotsu M, Morooka S, Suzuki T: Chronic encapsulated intracerebral hematoma associated with cavernous angioma: a case report. Neuroradiology 26: 700-702, 1990

23) Nanto $M$, Sugawa $N$, Tenjin $H$ : [A chronic intracerebral hematoma for which corticosteroid was effective: case report]. No Shinkei Geka 31: 49-54, 2003 (Japanese) 
24) Okuno S, Hisanaga M, Miyasaki A, Tsunoda S, Sakaki T: [Chronic encapsulated intracerebral hematoma associated with cavernous angioma: case report and review of the literature]. No Shinkei Geka 21: 655-659, 1993 (Japanese)

25) Ooba H, Kamida T, Isono M, Kobayashi H, Karashima A, Yamashita M: Chronic intraventricular encapsulated hematoma presenting unique radiological features: a case report. Surg Neurol 59: 23-27, 2003

26) Pozzati E, Giuliani G, Gaist G, Piazza G, Vergoni G: Chronic expanding intracerebral hematoma. J Neurosurg 65: 611-614, 1986

27) Roda JM, Carceller F, Perez-Higueras A, Morales C: Encapsulated intracerebral hematomas: a defined entity: case report. J Neurosurg 78: 829-833, 1993

28) Sakaida H, Sakakura M, Tochio H, Nakao K, Taniguchi A, Yabana T: Chronic encapsulated intracerebral hematoma associated with angiographically occult arteriovenous malformation—case report. Neurol Med Chir (Tokyo) 33: 638-642, 1993

29) Sakamoto T, Oshio K, Hazama Y, Sekino H, Tadokoro M: [A chronic encapsulated expanding hematoma with cyst formation caused by rupture of arteriovenous malformation: a case report]. No Shinkei Geka 25: 73-77, 1997 (Japanese)

30) Steiger HJ, Markwalder TM, Reulen HJ: Clinicopathological relations of cerebral cavernous angiomas: observations in eleven cases. Neurosurgery 21: 879-884, 1987

31) Suyama Y, Kajikawa H, Yamamura K, Sumioka S, Kajikawa M, Tsuji S, Pant B, Ohama E: [A case report of chronic encapsulated intracerebral hematoma]. No Shinkei Geka 24: 487-491, 1996 (Japanese)
32) Takahashi N, Kikuchi H, Kobayashi K, Karasawa J: [Multilocular encapsulated intracerebral hematoma]. No Shinkei Geka 11: 739-743, 1983 (Japanese)

33) Takeuchi S, Takasato Y, Masaoka H, Hayakawa T, Otani N, Yoshino Y, Yatsushige H, Sugawara T: Development of chronic encapsulated intracerebral hematoma after radiosurgery for a cerebral arteriovenous malformation. Acta Neurochir (Wien) 151: 1513-1515, 2009

34) Terada T, Okuno T, Moriwaki H, Nakai E, Komai N: Chronic encapsulated intracerebral hematoma during infancy: case report. Neurosurgery 16: 833-835, 1985

35) Tomiyama A, Aoki K, Sato K, Nakayama H, Harashina J, Hayashi M, Kimura H, Sakurai T, Iwabuchi S, Takahashi K, Terada H, Ueda M, Samejima H: [A case of encapsulated intracerebral hematoma mimicking metastatic brain tumor]. No Shinkei Geka 34: 851-856, 2006 (Japanese)

36) Tsuruta W, Tsuboi K, Nose T: Serial neuroimaging of encapsulated chronic intracerebral hematoma with repeated hemorrhage-case report. Neurol Med Chir (Tokyo) 43: 439-442, 2003

37) Yamashita T, Yamamoto S: How do vessels proliferate in the capsule of a chronic subdural hematoma? Neurosurgery 15: 672-678, 1984

Address reprint requests to: Kosuke Miyahara, MD, Department of Neurosurgery, National Hospital Organization Yokohama Medical Center, 3-60-2 Harajuku, Totsuka-ku, Yokohama, Kanagawa 245-8575, Japan. e-mail: kosukemiyahara@jk9.so-net.ne.jp 